
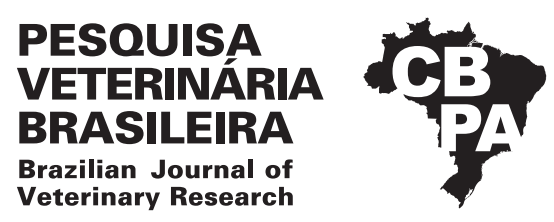

Pesq. Vet. Bras. 39(5):324-331, May 2019 DOI: 10.1590/1678-5150-PVB-5520

ISSN 0100-736X (Print) ISSN 1678-5150 (Online)

\title{
Effect of eCG on the follicular dynamics and vascularization of crossbred cows with different circulating progesterone concentrations during synchronization of ovulation in an FTAI protocol ${ }^{1}$
}

\author{
Priscila A. Ferraz ${ }^{2 *}$ (D), Mariana A.A. Silva², Bia S.S. Carôso², Endrigo A.B. Araujo², \\ Thereza C.B.S.C. Bittencourt ${ }^{2}$, Marcos Chalhoub ${ }^{2}$, Rodrigo F. Bittencourt ${ }^{2}$ \\ and Antonio L. Ribeiro Filho ${ }^{2}$
}

\begin{abstract}
Ferraz P.A., Silva M.A.A., Carôso B.S.S., Araujo E.A.B., Bittencourt T.C.B.S.C., Chalhoub M., Bittencourt R.F. \& Ribeiro Filho A.L. 2019. Effect of eCG on the follicular dynamics and vascularization of crossbred cows with different circulating progesterone concentrations during synchronization of ovulation in an FTAI protocol. Pesquisa Veterinária Brasileira 39(5):324-331. Departamento de Anatomia, Patologia e Clínicas Veterinárias, Universidade Federal da Bahia, Rua Ademar de Barros 500, Ondina, Salvador, BA 40170-110, Brazil. E-mail: prisferraz@gmail.com

This study aimed to evaluate the effect of treatment with equine chorionic gonadotrophin (eCG) on the follicular dynamics and function of crossbred cows with different circulating progesterone (P4) concentrations during synchronization of ovulation in a fixed-time artificial insemination (FTAI) protocol. To this end, 30 crossbred cows were submitted to a pre-synchronization protocol to ensure that all of them presented corpus luteum (CL) at the beginning of the protocol, and were evaluated by transrectal ultrasonography (TRUS) to verify the presence of CL. After that, the animals underwent an ovulation synchronization protocol and evaluation of follicular dynamics and vascularization by B-mode and power-Doppler ultrasound (US). High plasma P4 concentrations at the time of ovulation synchronization negatively influenced follicle diameter on day 10 (D10), preovulatory follicle diameter, and preovulatory follicle wall vascularization area $(p<0.05)$. Cows with high $\mathrm{P} 4$ concentration at the time of ovulation synchronization that were treated with eCG showed follicle diameter on D10 and preovulatory follicle diameter and wall vascularization area $(p>0.05)$ similar to those of animals with low P4 concentration at the time of ovulation synchronization. Therefore, high P4 concentrations at the time of ovulation synchronization negatively influence follicular diameter and vascularization, and eCG can be used as a strategy to favor better follicular and luteal response in crossbred cows with high P4 concentrations submitted to an FTAI protocol.
\end{abstract}

INDEX TERMS: Effect of eCG, follicular vascularization, crossbred cows, progesterone, ovulation, FTAI protocol, cattle, equine chorionic gonadotrophin, synchronization, Doppler, clinics.

\footnotetext{
RESUMO.- [Efeito do eCG na dinâmica e na vascularização folicular de vacas mestiças com diferentes concentrações circulantes de progesterona durante a sincronização de ovulação em um protocolo IATF.] Objetivou-se neste estudo avaliar o efeito do tratamento com gonadotrofina coriônica equina (eCG) sobre a dinâmica e função folicular

${ }^{1}$ Received on October 21, 2018.

Accepted for publication on November 21, 2018.

${ }^{2}$ Departamento de Anatomia, Patologia e Clínicas Veterinárias, Universidade Federal da Bahia (UFBA), Rua Ademar de Barros 500, Ondina, Salvador, BA 40170-110, Brazil. *Corresponding author: prisferraz@gmail.com
}

em fêmeas mestiças com diferentes concentrações circulantes de P4 durante a sincronização da ovulação em um protocolo de IATF. Para tanto, foram utilizadas 30 fêmeas mestiças e submetidas a um protocolo de pré-sincronização para garantir que todos os animais apresentassem corpo lúteo (CL) no início do protocolo, sendo avaliadas por ultrassonografia (US) transretal para a verificação da presença ou não de CL. Em seguida foram submetidas a um protocolo de sincronização da ovulação e avaliação da dinâmica e vascularização folicular por ultrassonografia (US) em modo B e Doppler colorido. Altas concentrações de P4 no momento da sincronização da ovulação impactaram negativamente no diâmetro do 
folículo no D10, o diâmetro do folículo pré-ovulatório e na área de vascularização da parede do folículo pré-ovulatório $(\mathrm{P}<0,05)$. As vacas com alta concentração de $\mathrm{P} 4$ no momento da sincronização da ovulação e que foram tratadas com eCG apresentaram diâmetro do folículo no D10 e no diâmetro e a área de vascularização da parede do folículo pré-ovulatório $(P>0,05)$, semelhantes às vacas que com baixa concentração de P4 no momento da sincronização da ovulação. Conclui-se que elevadas concentrações de P4 no momento da sincronização da ovulação impactam negativamente no diâmetro e vascularização folicular e que o eCG pode ser utilizado como uma estratégia para favorecer uma melhor resposta folicular e luteal em fêmeas mestiças com altas concentrações de P4 submetidas a um protocolo de IATF.

TERMOS DE INDEXAÇÃO: Efeito do eCG, vascularização folicular, vacas mestiças, progesterona, ovulação, protocolo IATF, bovinos, gonadotrofina coriônica equina, sincronização, doppler, clínica.

\section{INTRODUCTION}

Brazilian cattle rasing has greatly advanced throughout the years with enormous quantitative and qualitative gain to its herd, and the incorporation of biotechnology has contributed to the prominent position the Country currently occupies in the global livestock sector (Baruselli et al. 2012). In this context, animal breeding biotechnologies play an important role in the dissemination of high quality genetics, increase of reproductive indexes, and improvement in the reproductive efficiency of cattle herds (Bó et al. 2013).

Fixed-time artificial insemination (FTAI) stand out among the most widely used biotechnologies in Brazil (Baruselli et al. 2012). This protocol allows insemination procedures to be conducted at predetermined times, eliminating the need for estrus detection (Sá Filho et al. 2010). Currently, FTAI is a quite widespread biotechnology, showing an advanced level of development; however, its reproductive rates range from 35 to $55 \%$, and these results can be improved by enhancing the synchronization protocols (Bó et al. 2013).

Several hormonal treatments have been developed to support FTAI (Sá Filho et al. 2010). In Brazil, the most commonly used protocols are based on use of progesterone (P4) intravaginal devices associated with administration of estradiol benzoate (EB) at the beginning of treatment, day 0 (D0), on a random day of the oestrous cycle. Upon removal of the P4 intravaginal device, day 8 (D8), prostaglandin (PGF2 $\alpha$ ) is applied together with estradiol cypionate (EC) or with administration of EB after $24 \mathrm{~h}$, and FTAI is usually performed up to $56 \mathrm{~h}$ after device removal (Baruselli et al. 2012).

It has been reported that circulating P4 concentrations during the protocol of ovulation synchronization for FTAI influence the probability of conception through changes in the follicular and luteal functions (Wiltbank et al. 2014). In addition, the breed and level of milk production of animals are of major importance (Carvalho et al. 2008). Nevertheless, there is still lack of scientific evidence regarding the impact of P4 concentration on ovulation synchronization in crossbred cows.

Strategies have been developed to favor follicular development in the synchronization protocols and the positive effect of eCG on stimulating follicular growth, consequently increasing ovulation rate in FTAI protocols (Sá Filho et al. 2010). The eCG is a long half-life glycoprotein produced in the endometrial calyces of the pregnant mare that binds to the receptors of follicle-stimulating (FSH) and luteinizing ( $\mathrm{LH})$ hormones of the follicles and to the LH receptors of the corpus luteum (CL) (Murphy 2012). Thus, some studies indicate that the positive effect of eCG on conception rates is due to the ability of this hormone to promote an increase in the absolute steroidogenic capacity of the CL (Rigoglio et al. 2013) and induce changes at the tissue, cellular and molecular levels that are associated with increase in functional capacity and progesterone synthesis of this structure (Fátima et al. 2012), and this is essential to favor better results for synchronization protocols.

Inclusion of eCG in the FTAI protocol may improve the follicular function of bovine females, which are challenged with high circulating P4 concentrations. However, the effects of this gonadotrophin on crossbred cows with different circulating P4 concentrations in an FTAI protocol are still scarce. In this context, this study aimed to assess the effect of eCG on the follicular dynamics and vascularization of crossbred cows with different plasma P4 concentrations during the ovulation synchronization in an FTAI protocol.

\section{MATERIALS AND METHODS}

Location and management of the animals. The study was conducted from May to August, 2016 at the Entre Rios experimental farm, "Escola de Medicina Veterinária e Zootecnia”, "Universidade Federal da Bahia" (UFBA), located in the municipality of Entre Rios, in the northeast region of Bahia state, Brazil ( $11^{\circ} 56^{\prime} 31^{\prime \prime} \mathrm{S}, 38^{\circ} 05^{\prime} 04^{\prime \prime} \mathrm{W}$ ), $162 \mathrm{~m}$ a.s.l.. Climate in the study region is hot and semi-humid and mean annual rainfall is $1,251 \mathrm{~mm}$. Animals in the farm were kept under extensive rearing, grazing on Brachiaria decumbens pasture with mineralized salt supplementation and access to water ad libitum. Thirty multiparous, Holstein-Friesian x Gir crossbred cows were used in this study. These animals were at $77.34 \pm 22.13$ day post-partum, showed lactation duration of $279.67 \pm 58.67$ days, average daily milk production of $4.85 \pm 0.83 \mathrm{~kg}$, and average body condition score (BCS) of $3.07 \pm 0.38$ in a $1-5$ scale (Houghton et al. 1990). The experimental farm was in compliance with the official immunization schedule. Prior to study commencement, the animals were submitted to clinical gynecological examination and TRUS using a 7.5MHz frequency linear transducer (Mindray z5, Shenzhen, China), and only the cows with absence of abnormality in the reproductive tract at the time of assessment were included in the study.

Synchronization protocol. The 30 multiparous, Holstein-Friesian x Gir crossbred cows were submitted to the same pre-synchronization protocol to ensure that all animals presented corpus luteum (CL) at the beginning of the protocol as described ahead: on a random day of the oestrous cycle, named day minus 16 (D-16), all animals received a new intravaginal P4 device ( $\mathrm{CIDR}^{\circledR}$, Zoetis, São Paulo, Brasil) containing $1.9 \mathrm{~g}$ progesterone (P4) plus $2 \mathrm{mg}$ estradiol benzoate (EB) (Gonadiol $^{\circledR}$, Zoetis, São Paulo, Brasil) intramuscularly (IM). On day minus 8 (D-8), the intravaginal P4 device was removed and $12.5 \mathrm{mg}$ of Dinoprost tromethamine (PGF2 $\alpha$ ) (Lutalyse ${ }^{\circledR}$, Zoetis, São Paulo, Brasil) were administered IM, followed by $0.6 \mathrm{mg}$ estradiol cypionate (EC) (ECP ${ }^{\circledR}$, Zoetis, São Paulo, Brasil) IM.

Eight days after removal of the P4 devices, on day 0 (D0), all animals were evaluated by B-mode TRUS using a 7.5 MHz frequency linear transducer (Mindray z5, Shenzhen, China) to verify the presence of CL. After the ultrasound (US) assessment on D0, only 26 cows were submitted to a synchronization protocol and received a new intravaginal P4 device (CIDR ${ }^{\circledR}$, Zoetis, São Paulo, Brasil) containing 
1.9g P4 plus 2mg EB (Gonadiol ${ }^{\circledR}$, Zoetis, São Paulo, Brasil) IM; on the same day, half of the animals were treated with $12.5 \mathrm{mg}$ PGF2 $\alpha$ IM (Lutalyse ${ }^{\circledR}$, Zoetis, São Paulo, Brasil), whereas the other half was treated with $1.5 \mathrm{~mL}$ saline solution at $0.9 \% \mathrm{IM}$, and thus the following study groups were formed: High P4 concentration (cows that did not receive PGF2 $\alpha$ at the beginning of the synchronization protocol (D0); $n=13$ ) and Low P4 concentration (animals that received PGF2 $\alpha$ at the beginning of the synchronization protocol (D0); $\mathrm{n}=13$ ). On day 8 (D8), the intravaginal P4 devices were removed and $12.5 \mathrm{mg}$ PGF2 $\alpha$ (Lutalyse $^{\circledR}$, Zoetis, São Paulo, Brasil) plus 0.6mg EC $\left(\mathrm{ECP}^{\circledR}\right.$, Zoetis, São Paulo, Brasil) were administered IM to all cows.

At this time, the crossbred cows were randomly separated to be treated with 300UI eCG (FOLLIGON ${ }^{\circledR}$, MSD Saúde Animal, São Paulo, Brasil) or $1.5 \mathrm{~mL}$ saline solution at $0.9 \%$ IM. Thus, of the 13 cows that were not treated with PGF2 $\alpha$ on D0, six were treated with saline solution (High $\mathrm{P} 4-\mathrm{S} / \mathrm{eCG} ; \mathrm{n}=6$ ) and seven were treated with eCG (High P4-C/eCG; n=7), whereas of the 13 animals treated with PGF $2 \alpha$ on D0, six received saline solution (Low $\mathrm{P} 4-\mathrm{S} / \mathrm{eCG} ; \mathrm{n}=6$ ) and seven received eCG (Low $\mathrm{P} 4-\mathrm{C} / \mathrm{eCG} ; \mathrm{n}=7$ ). No intravaginal P4 device losses were observed in this study.

Ultrasound (US) assessment. US assessments were performed using a portable device equipped with the B-mode and power-Doppler functions (Mindray z5, Shenzhen, China): a 7.5 MHz frequency transrectal transducer was used for the B-mode examinations, whereas for the power-Doppler assessments, the device was adjusted to $6 \mathrm{~cm} / \mathrm{s}$ velocity range in order to detect movement of blood cells in small vessels; to this end, the power-flow mode was used at a frequency of $8.5 \mathrm{Mhz}, 70 \%$ color gain standards, $0.7 \mathrm{KHz}$ pulse repetition frequency (PRF), and $6 \mathrm{~cm}$ depth of evaluation.

Follicular dynamics were performed every $12 \mathrm{~h}$ through B-mode and power-Doppler US, starting on D8 until ovulation, or up to $96 \mathrm{~h}$ after removal of the intravaginal P4 device. Ovulation was defined by the non-observance of the largest follicle present in the previous examination, which was defined as preovulatory follicle, and with consequent CL formation. The preovulatory follicle growth rate (PFGR) was obtained by the difference between the preovulatory follicle diameter (PFD) and the dominant follicle diameter in the first assessment on D8 (DFD8) divided by the growth period and expressed as millimeters per day $(\mathrm{mm} / \mathrm{d})$. The total area of the dominant follicle of each animal was also calculated, and then the inner wall follicle area was subtracted from the outer wall follicle area, so that the total dominant follicle wall area on D8 (DFWA8) and D10 (DFWA10) of the synchronization protocol could be determined, as well as the preovulatory follicle wall area (PFWA). Subsequently, the power-Doppler US images were stored in order to calculate the dominant follicle wall vascularization area on D8 (DFWVA8) and D10 (DFWVA10) of the synchronization protocol, as well as the total preovulatory follicle wall vascularization area (PFWVA). To this end, the total follicle wall vascularization area of each cow was calculated using a function of the US device. The percentages of dominant follicle wall vascularization area were evaluated on D8 (\%DFWVA8) and D10 (\%DFWVA10) of the synchronization protocol, as well as the percentage of preovulatory follicle wall vascularization area (\%PFWVA), which was obtained by dividing the follicle wall vascularization area by the total follicle wall area according to the methodology proposed by Rodrigues (2016), as illustrated in Figure 1.

Blood collection and hormone dosing. Blood samples for plasma $\mathrm{P} 4$ content dosing were collected at different times of the protocol: days $0,8,10$, and 24 , through puncture of coccygeal vessels, into $10 \mathrm{~mL}$ vacuum tubes without anticoagulant (VACUTAINERR, Becton, Dickinson and Company, Franklin Lakes/NJ, USA) and immediately stored in styrofoam containers with ice at $4^{\circ} \mathrm{C}$. Subsequently, the blood samples were centrifuged at 3,000G for $15 \mathrm{~min}$ for serum separation, transferred to labeled polyethylene microtubes, and stored at $-20^{\circ} \mathrm{C}$ until analysis. Analyses of $\mathrm{P} 4$ concentration were conducted according to the chemiluminescence method using the Access Immunoassay System (Beckman Coulter, Fullerton/CA, USA) at the Laboratório de Imunologia do Instituto de Ciências da Saúde (ICS) of UFBA. Inter-assay coefficient of variation (CV) was $2.6 \%$ and assay sensitivity was $0.006 \mathrm{ng} / \mathrm{mL}$. The highest and lowest inter-assay CVs were $6.4 \%$ and $0.7 \%$, respectively.

Experimental design and statistical procedures. The four study groups were arranged in a $2 \times 2$ completely randomized factorial design: first factor, application of PGF $2 \alpha$ on protocol D0 (levels of 0 and $12.5 \mathrm{mg}$ ); second factor, application of eCG on protocol D8 (levels of 0 and 300 UI). Data were processed using the Statistical Package for Social Science 19.0 (SPSS 2012) software. Statistical analysis was as follows: 1) Mean and standard deviation of the variables of interest to the study were obtained through descriptive analysis; 2) Differences between the variables of interest: dominant and preovulatory follicle diameters (DFD8, DFD10, and PFD), preovulatory follicle growth rate (PFGR), dominant and preovulatory follicle wall areas (DFWA8, DFWA10, and PFWA), dominant and preovulatory follicle wall vascularization area (DFWVA8, DFWVA10, and PFWVA), percentages of dominant and preovulatory follicle wall
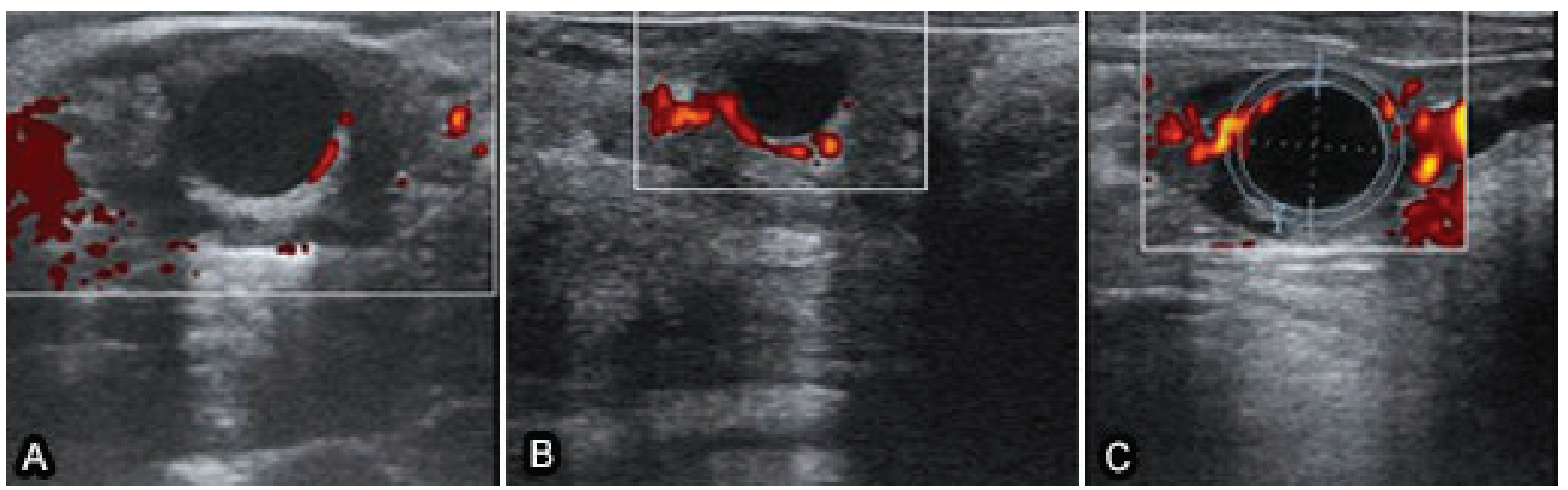

Fig.1. Power-Doppler US images of (A) low vascularization follicle, (B) high vascularization follicle, and (C) follicle with delimited irrigated area. 
vascularization areas (\%DFWVA8, \%DFWVA10, and \%PFWVA), and analyses of circulatiing progesterone concentrations (P4D0, P4D8, and P4D10) for the different study groups were assessed by analysis of variance (ANOVA) with subsequent application of the Tukey's test. Comparison between the aforementioned variables of interest was performed using repeated measures ANOVA. A significance level of $5 \%$ was adopted for all statistical analyses. This study was approved by the Ethics Committee on Animal Use (CEUA) of EMEVZ-UFBA under protocol no. 41/2016.

\section{RESULTS}

Of the 30 crossbred cows initially included in the study, four did not ovulate to the pre-synchronization protocol and were excluded from this phase of the experiment. Therefore, 26 cows remained for the analysis of follicular dynamics and function and were distributed into study groups as follows: High P4-S/eCG $(n=6)$, High P4-C/eCG ( $n=7)$, Low P4-S/eCG $(n=6)$, and Low P4-C/eCG $(n=7)$. No interaction was observed between the treatments regarding the variables of interest. In this study, the presence of a corpus luteum (CL) at the beginning of the synchronization protocol for FTAI significantly increased the circulating progesterone (P4) concentration at the time of ovulation synchronization. This hormonal scenario negatively influenced the dominant follicle diameter on day 10 (D10) $(p=0.01)$, the preovulatory follicle diameter $(p=0.02)$, and the preovulatory follicle wall vascularization area $(p=0.04)$ compared with those of cows with low P4 concentrations (Table 1 and Fig.2). In the comparison between treatments over time, the variables total dominant and preovulatory follicle wall area and diameter were significantly affected $(p<0.05)$; however, in the variables dominant and preovulatory follicle wall vascularization areas $(p=0.26)$ and percentages of dominant and preovulatory follicle wall vascularization areas $(p=0.79)$, no statistically significant differences were observed between the study groups over time, suggesting that all synchronization protocols equitably stimulated follicular vascularization.

In this study, administration of eCG upon removal of the intravaginal P4 device in cows with high plasma P4 concentration at the time of ovulation synchronization was able to equate the dominant follicle diameter on D10 $(p>0.05)$, the preovulatory follicle diameter $(p>0.05)$, and the preovulatory follicle wall vascularization area $(p>0.05)$ of these cows with those of animals with low circulating P4 concentration (Table 1 and Fig.2).

With respect to the time of ovulation, cows with high circulating P4 concentration had a longer interval between removal of intravaginal P4 device and ovulation compared with those with low plasma P4 concentration $(p<0.05)$.

Table 1. Mean and standard deviation of the parameters follicular dynamics ( $\mathrm{mm}$ and $\mathrm{cm}^{2}$ ), follicular growth rate $(\mathrm{mm} / \mathrm{d})$, follicular vascularization $\left(\mathrm{cm}^{2}\right.$ and \%), and time of ovulation (h) assessed by B-mode and power-Doppler US and plasma progesterone (P4) concentration $(\mathrm{ng} / \mathrm{mL})$ on days 0,8 , and 10 of the synchronization protocol for the different study groups in crossbred cows

\begin{tabular}{|c|c|c|c|c|c|c|}
\hline \multirow[b]{2}{*}{ Variables } & \multicolumn{4}{|c|}{ Study groups } & \multirow[b]{2}{*}{$p$-value } & \multirow[b]{2}{*}{ Overall $(n=26)$} \\
\hline & $\begin{array}{c}\text { High P4-S/eCG } \\
(n=6)\end{array}$ & $\begin{array}{c}\text { High P4-C/eCG } \\
(n=7)\end{array}$ & $\begin{array}{c}\text { Low P4-S/eCG } \\
(n=6)\end{array}$ & $\begin{array}{c}\text { Low P4-C/eCG } \\
(n=7)\end{array}$ & & \\
\hline DFD8 (mm) & $8.70 \pm 2.10$ & $9.37 \pm 1.40$ & $10.78 \pm 2.31$ & $11.67 \pm 2.55$ & 0.06 & $10.19 \pm 2.35$ \\
\hline DFD10 (mm) & $8.78 \pm 2.04 \mathrm{a}$ & $10.67 \pm 1.65 \mathrm{ab}$ & $13.12 \pm 3.52 b$ & $13.37 \pm 2.34 b$ & 0.01 & $11.46 \pm 2.93$ \\
\hline PFD (mm) & $9.48 \pm 2.12 \mathrm{a}$ & $11.82 \pm 2.64 \mathrm{ab}$ & $13.66 \pm 2.58 b$ & $14.17 \pm 2.22 \mathrm{~b}$ & 0.02 & $12.36 \pm 2.91$ \\
\hline PFGR (mm/dia) & $0.03 \pm 0.02$ & $0.05 \pm 0.01$ & $0.07 \pm 0.02$ & $0.07 \pm 0.03$ & 0.52 & $0.06 \pm 0.02$ \\
\hline DFWA8 $\left(\mathrm{cm}^{2}\right)$ & $0.33 \pm 0.13$ & $0.42 \pm 0.12$ & $0.51 \pm 0.17$ & $0.56 \pm 0.17$ & 0.53 & $0.46 \pm 0.17$ \\
\hline DFWA10 $\left(\mathrm{cm}^{2}\right)$ & $0.25 \pm 0.14 \mathrm{a}$ & $0.52 \pm 0.25 \mathrm{ab}$ & $0.58 \pm 0.24 \mathrm{ab}$ & $0.67 \pm 0.12 b$ & 0.01 & $0.51 \pm 0.23$ \\
\hline $\operatorname{PFWA}\left(\mathrm{cm}^{2}\right)$ & $0.33 \pm 0.12 \mathrm{a}$ & $0.47 \pm 0.13 \mathrm{ab}$ & $0.54 \pm 0.25 \mathrm{ab}$ & $0.64 \pm 0.17 b$ & 0.02 & $0.50 \pm 0.20$ \\
\hline DFWVA8 $\left(\mathrm{cm}^{2}\right)$ & $0.07 \pm 0.04$ & $0.08 \pm 0.04$ & $0.13 \pm 0.06$ & $0.14 \pm 0.01$ & 0.23 & $0.10 \pm 0.06$ \\
\hline DFWVA10 $\left(\mathrm{cm}^{2}\right)$ & $0.11 \pm 0.04 \mathrm{a}$ & $0.18 \pm 0.10 \mathrm{~b}$ & $0.17 \pm 0.04 \mathrm{ab}$ & $0.17 \pm 0.08 \mathrm{ab}$ & 0.34 & $0.16 \pm 0.07$ \\
\hline $\operatorname{PFWVA}\left(\mathrm{cm}^{2}\right)$ & $0.09 \pm 0.04 \mathrm{a}$ & $0.15 \pm 0.05 \mathrm{ab}$ & $0.18 \pm 0.09 \mathrm{~b}$ & $0.18 \pm 0.04 b$ & 0.04 & $0.15 \pm 0.06$ \\
\hline \%DFWVA8 (\%) & $16.67 \pm 12.37$ & $18.86 \pm 6.33$ & $29.00 \pm 12.88$ & $21.20 \pm 3.49$ & 0.12 & $21.92 \pm 10.68$ \\
\hline \%DFWVA10 (\%) & $20.29 \pm 10.49$ & $24.83 \pm 15.14$ & $22.00 \pm 7.98$ & $32.80 \pm 2.96$ & 0.59 & $24.27 \pm 5.95$ \\
\hline \%PFWVA (\%) & $42.17 \pm 15.31$ & $37.29 \pm 21.53$ & $25.29 \pm 6.10$ & $32.80 \pm 12.27$ & 0.26 & $34.20 \pm 15.89$ \\
\hline TO (h) & $96.00 \pm 13.14 \mathrm{a}$ & $94.29 \pm 10.79 a$ & $74.40 \pm 21.46 \mathrm{ab}$ & $61.50 \pm 11.89 b$ & 0.03 & $80.77 \pm 20.23$ \\
\hline P4D0 (ng/mL) & $4.58 \pm 1.06$ & $5.94 \pm 3.49$ & $6.54 \pm 3.21$ & $5.48 \pm 3.40$ & 0.38 & $5.60 \pm 2.91$ \\
\hline P4D8 (ng/mL) & $7.56 \pm 3.70 \mathrm{a}$ & $7.95 \pm 2.90 \mathrm{a}$ & $1.72 \pm 1.16 \mathrm{~b}$ & $1.55 \pm 0.74 b$ & 0.001 & $4.69 \pm 2.87$ \\
\hline P4D10 (ng/mL) & $0.25 \pm 0.51$ & $0.52 \pm 0.31$ & $0.36 \pm 0.18$ & $0.41 \pm 0.16$ & 0.48 & $0.51 \pm 0.47$ \\
\hline
\end{tabular}

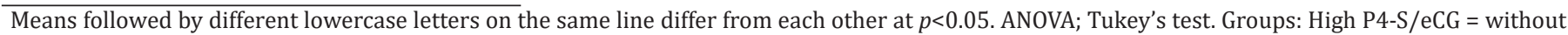

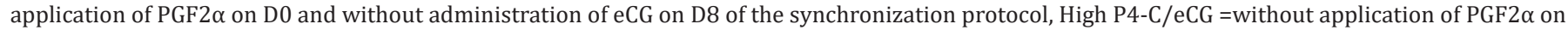

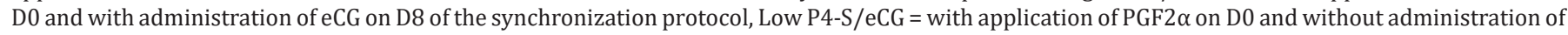

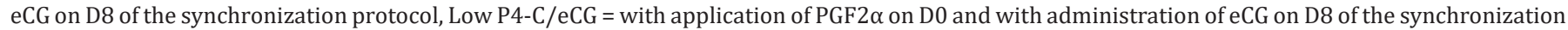

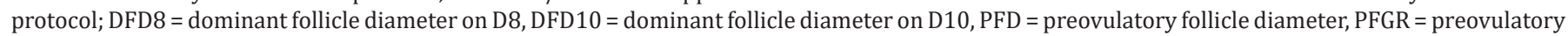

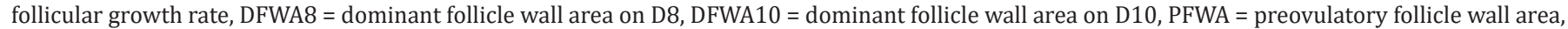

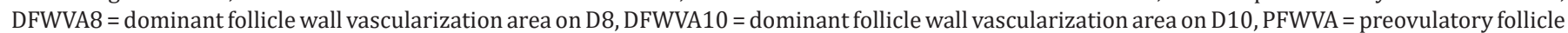

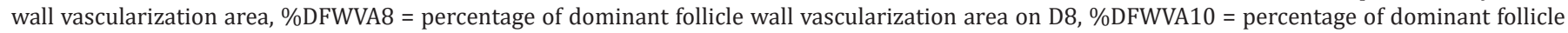

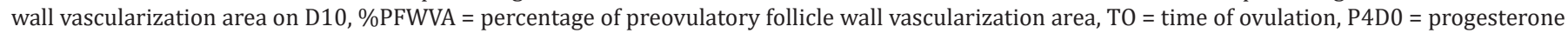
concentration on D0, P4D8 = progesterone concentration on D8, P4D10 = progesterone concentration on D10. 

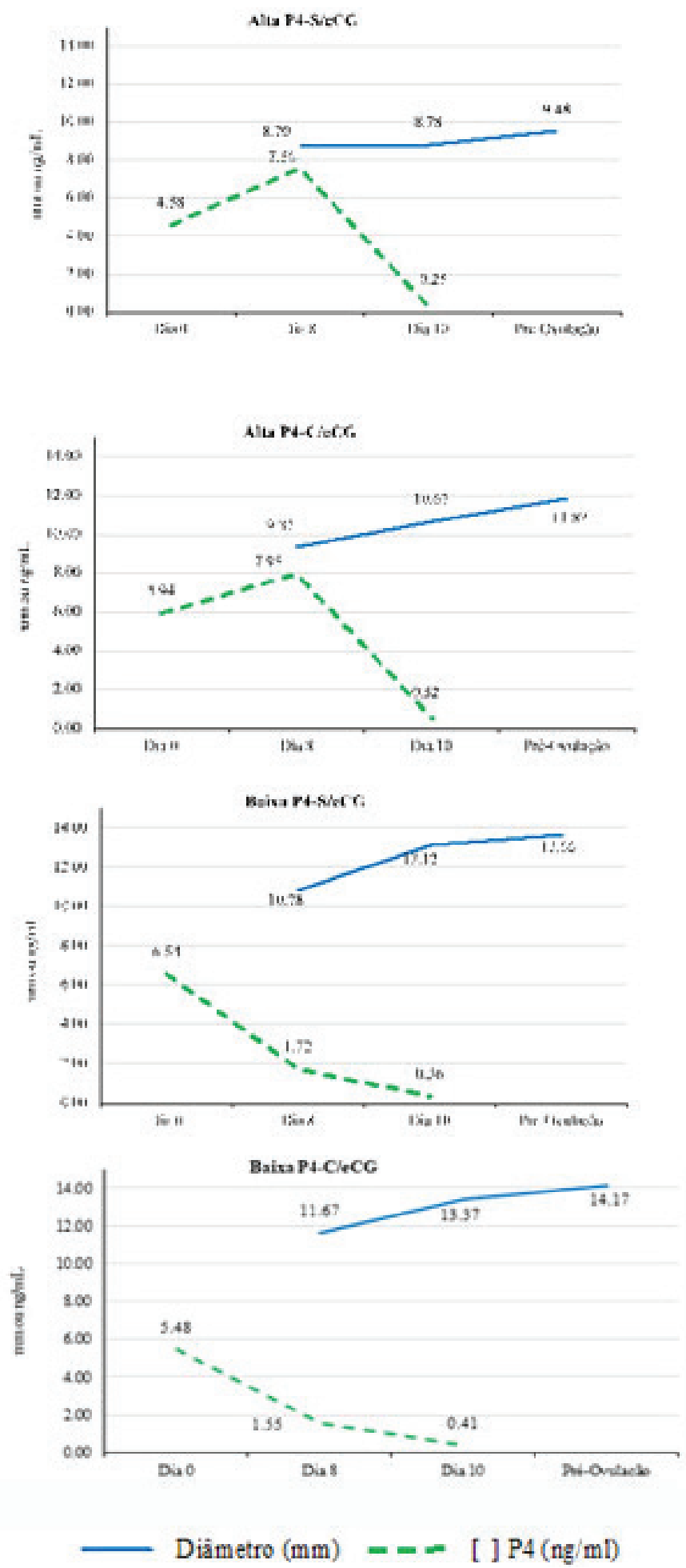

Fig.2. Dominant follicle diameter ( $\mathrm{mm}$ ) on days 8 and 10 . Preovulatory follicle diameter $(\mathrm{mm})$ and circulating progesterone concentration $(\mathrm{ng} / \mathrm{mL}$ ) on days 0,8 , and 10 of the synchronization protocol for the different study groups.

In addition, it was observed that cows with low circulating P4 concentration treated with eCG ovulated earlier than those with low serum P4 concentration at the time of ovulation synchronization that did not receive eCG $(p=0.03$, Table 1$)$.
Cows that were not treated with PGF2 $\alpha$ at the beginning of the synchronization protocol showed higher circulating P4 concentration on D8 ( $p=0.001$; Table 1$)$ on average at this time, that is, at the end of the luteal phase and ovulation synchronization. These animals presented plasma P4 concentration of $7.76 \mathrm{ng} / \mathrm{mL}$; it is worth noting that this high concentration results from endogenous (CL) and exogenous (intravaginal device) P4 sources. Cows that received PGF2 $\alpha$ at the beginning of the synchronization protocol showed lower circulating P4 concentration on D8 ( $p=0.00$, Table 1 ) on average at this time, that is, these animals presented plasma $\mathrm{P} 4$ concentration of $1.64 \mathrm{ng} / \mathrm{mL}$, and this concentration results only from an exogenous (intravaginal device) P4 source.

\section{DISCUSSION}

Findings of the present study emphasize the importance of an adequate endocrine environment during growth and maturation of ovulatory follicle in synchronization for FTAI protocols. Studies have reported that high preovulatory plasma P4 concentrations may decrease the efficiency of the synchronization protocols for FTAI (Pfeifer et al. 2009, Pergorer et al. 2011), and may be associated with reduction in the LH pulsatility, triggering a decrease in follicular development and, consequently, in the preovulatory follicle diameter (Sales et al. 2015). The mechanism by which high circulating P4 concentrations negatively influence FTAI results in beef cattle may be linked to reduction of the $\mathrm{LH}$ pulsatility and, therefore, to decreased dominant follicle diameter (Savio et al. 1993).

Results of this research corroborate those reported by Pergorer et al. (2011), who used administration or not of PGF2 $\alpha$ at the beginning of the synchronization protocol for FTAI in Nellore heifers aiming to provide a hormonal environment with different circulating P4 concentrations, and observed that low preovulatory plasma P4 concentrations increased the frequency of LH pulses, favoring follicular growth and increase in dominant follicle diameter (High P4: $10.3 \pm 0.22 \mathrm{~mm}$ and Low P4: $9.3 \pm 0.21 \mathrm{~mm}$ ), thus allowing this follicle to reach a larger ovulatory diameter.

Similar results were found by Pfeifer et al. (2009) when studying the effect of circulating $\mathrm{P} 4$ concentration on a synchronization protocol for FTAI on follicular dynamics and hormonal profile in Bos taurus taurus beef cows. They observed that cows with low serum P4 concentration showed larger dominant $(14.3 \pm 0.51 \mathrm{~mm})$ and ovulatory $(16.5 \pm 0.52 \mathrm{~mm})$ follicles compared with those of cows in the high circulating P4 concentration group (dominant: $12.3 \pm 0.34$ and ovulatory: $14.2 \pm 0.34 \mathrm{~mm}$ follicles). Carvalho et al. (2008) conducted a study with cyclic crossbred heifers submitted or not to application of PGF2 $\alpha$ on D0 of the synchronization protocol aiming to obtain animals with and without CL at the beginning of the protocol, and verified that high preovulatory circulating P4 concentrations compromised the growth of the dominant and preovulatory follicle diameters - animals with high plasma P4 concentration showed smaller dominant and preovulatory follicle diameters $(10.5 \pm 0.4$ and $11.7 \pm 0.5 \mathrm{~mm})$ compared with those of cows with low circulating P4 concentration (11.9 \pm 0.4 and $12.6 \pm 0.4 \mathrm{~mm})$. Corroborating the findings of the present survey, Sá Filho et al. (2010) conducted a study with Bos indicus (Nelore) heifers in the presence and absence of $\mathrm{CL}$ at the beginning of the synchronization protocol using 
Norgestomet and EB, and verified that the preovulatory follicle diameter at the time of removal of the intravaginal $\mathrm{P} 4$ device was higher in animals that did not show CL at the start of treatment. In addition, they observed that these heifers had lower follicular growth rate and reduced CL diameter after the protocol, as well as lower conception rate.

Overall, the findings of the present study are in agreement with the literature, which describes that a scenario with low plasma P4 concentration stimulates a pattern of LH release of high frequency and low amplitude, promoting hormonal environment for follicular development and maturation; so with the increased frequency of LH pulses, the dominant follicle continues its growth and reaches an adequate diameter and high concentrations of estradiol, becoming responsive to the induction of the preovulatory peak of LH and to ovulation (Roberson et al. 1989).

Application of eCG is a strategy that can be used in animals that present limitation in LH pulsatility due to high preovulatory plasma P4 concentration. This glycoprotein has a positive effect on the development of the dominant follicle, increase of ovulatory follicle size, and improvement in ovulation rate (Dias et al. 2009, Peres et al. 2009). The results of the present research are in agreement with those observed by Dias et al. (2009) and Peres et al. (2009), who reported that application of eCG promotes a stimulus to the release of gonadotropins, and thus can provide adequate gonadotrophic support for the development of the ovulatory follicle. Therefore, eCG administration is a strategy to mitigate the negative effect of high circulating P4 concentrations at the time of ovulation synchronization in FTAI protocols.

Sá Filho et al. (2010) evaluated the influence of the presence or absence of $\mathrm{CL}$ at the beginning of the FTAI protocol using Norgestomet and BE in Nellore heifers that received or not $400 \mathrm{UI}$ of eCG at the time of ovulation synchronization. They observed a positive effect of eCG treatment on increasing the dominant follicle diameter on D8 and D10 of the protocol, follicular growth rate, and ovulation rate of the animals and, similarly to the findings of the present study, heifers with CL that did not receive eCG at the time of removal of the intravaginal P4 device showed smaller ovulatory follicle diameter at D10 $(9.4 \pm 0.3 \times 10.6 \pm 0.3 \mathrm{~mm})$ and reduced follicular growth rate $(0.68 \pm 0.1 \times 1.25 \pm 0.1 \mathrm{~mm} /$ day) compared with those that showed $\mathrm{CL}$ at the beginning of the protocol and received eCG at the time of removal of the intravaginal P4 device. Moreover, they observed that heifers that did not have CL at the beginning of the protocol and received eCG showed larger ovulatory follicle diameter on D10 of the protocol $(10.8 \pm 0.4 \times 9.6 \pm 0.5 \mathrm{~mm})$ and increased follicular growth rate $(0.86 \pm 0.2 \times 0.53 \pm 0.1 \mathrm{~mm} /$ day $)$ than those with no CL at the beginning of the protocol that did not receive eCG. According to De Rensis \& López-Gatius (2014), the positive effect of this glycoprotein can be attributed to the increase in steroidogenesis in the theca and follicular cells of the dominant and ovulatory follicles, fostering better follicular growth.

Contrary to the results of this study, Souza et al. (2009) investigated the follicular dynamics in Holstein-Friesian cows submitted to a synchronization protocol using $\mathrm{P} 4$ plus EB with or without application of eCG at the time of removal of the intravaginal P4 device and did not find a significant difference in the characteristics of the ovulatory follicle (without eCG: $14.3 \pm 0.5 \mathrm{~mm}$ and with eCG: $13.6 \pm 0.4 \mathrm{~mm}$ ) between cows that received gonadotrophin or not; however, Souza and collaborators did not consider the circulating P4 concentrations at the time of ovulation synchronization. Ferreira et al. (2013) developed an experiment to assess the effect of eCG on follicular and luteal parameters of high production dairy cows, and also did not observe effect on ovulatory follicle diameter for cows treated with eCG $(15.4 \pm 0.6 \mathrm{~mm})$ or not $(14.9 \pm 0.7 \mathrm{~mm})$ in a synchronization protocol for FTAI. They reported that the effect of eCG was evidenced only in cows with low BCS and in the post-partum anestrus period. According to Shephard (2013), animals in this physiological condition present insufficient LH support, inadequate dominant follicle growth, and subsequent failure in ovulation, or formation of CL with inefficient P4 production. Thus, treatment with eCG can increase gonadotrophin support to the follicle, improving follicular development and ovulation likelihood (Prata et al. 2017).

Although there are studies that associated follicular dynamics with blood flow of the follicles, and others that investigated the effect of different circulating P4 concentrations on the follicular and luteal parameters in cows submitted to an FTAI protocol, there is still lack of research characterizing follicular and luteal vascularization in animals with different hormonal scenarios and with or without administration of eCG in an ovulation synchronization protocol (Pfeifer et al. 2009).

According to Acosta et al. (2003), the follicle wall vascularization area is an indicator of follicular maturity prediction and ovulation proximity. Corroborating Acosta \& Miyamoto (2004), adequate blood flow to the follicle wall near the time of ovulation is essential to promote blood support to the follicular cells of gonadotrophins, nutrients, and hormone substrates necessary for follicular maturation and ovulation.

In this study, the preovulatory follicle wall vascularization area in crossbred cows with high plasma P4 concentration at the time of ovulation synchronization that were treated with eCG on the day of removal of the intravaginal P4 device was similar to that of animals with low circulating P4 concentration that received or not eCG. Results of the present survey for the ovulatory follicle wall vascularization area are in agreement with the literature, which describes that an increase in the follicular blood flow occurs along with the increase of the ovulatory follicle diameter in the preovulatory period, resulting in significant increase in follicle wall vascularization area (Siddiqui et al. 2009). In this research, it was observed that application of eCG promoted improvement in follicular development and vascularization in cows that had high circulating P4 concentrations at the beginning of the protocol, reducing their negative impact at the time of ovulation synchronization. This increase can be assigned to the fact that this gonadotrophin acts on the theca and follicular cells of the follicle and activates angiogenic factors and vasodilatory molecules, fostering increased blood flow (Honnens et al. 2009).

In the present research, the preovulatory follicle wall vascularization area of animals with CL at the beginning of the protocol that were treated with eCG on the day of removal of the intravaginal P4 device was similar to that of cows that did not present CL at the beginning of the protocol. The results found for the preovulatory follicle wall vascularization area corroborate the literature, which describes the occurrence of increased blood flow in the follicle wall and follicular growth 
in the peri-ovulatory period, resulting in significant increase in the follicle wall vascularization area (Acosta et al. 2003). These results may be explained by the fact that administration of eCG leads to increased follicular blood flow (Honnens et al. 2009). This increase can be attributed to activation of angiogenic factors and vasodilator molecules, as well as to the ability of this gonadotrophin to act in the theca and follicular cells of the follicle (Murphy 2012). Thus, eCG may have promoted improvement in follicular development and vascularization in the cows with CL at the beginning of the protocol, alleviating the negative effect of high preovulatory circulating P4 concentration.

These findings are in agreement with those reported by Acosta et al. (2003), who described the follicle wall vascularization area as a strategy to predict the maturity of this follicle and ovulation proximity. Siddiqui et al. (2009) observed positive and significant association of blood flow in the ovulatory follicle wall with oocyte maturity and embryonic development, and reported that follicles with higher vascularization percentage provide better supply of metabolites and increase in the action of several vasoactive factors essential for the process of follicular maturation. Increased blood flow to the follicle wall near the time of ovulation is essential to provide blood supply to follicular cells of gonadotrophins, nutrients, and hormone substrates required for follicle maturation and for ovulation (Acosta et al. 2003).

As for the time of ovulation, reduced circulating P4 concentration at the time of removal of the P4 intravaginal device is associated with the increased frequency of LH pulses, which stimulates dominant follicle growth and secretion of estradiol; this hormonal scenario allows this follicle to reach follicular maturity and ovulatory capacity, and thus the moment of ovulation occurs earlier (Dias et al. 2009, Peres et al. 2009). Similarly to the present study, Sales et al. (2015) assessed the effect of plasma P4 concentration during ovulation synchronization for an FTAI protocol in Nelore cows, and found that animals with low serum P4 concentration ovulated earlier $(68.4 \pm 2.3 \mathrm{~h})$ compared with cows with high circulating P4 concentration $(73.7 \pm 2.9 \mathrm{~h})$. This occurs because cows with low plasma P4 concentration present high concentrations of LH during dominant follicle growth, which leads to premature induction of LH receptors and ovulatory competence in these animals (Pfeifer et al. 2009).

Also corroborating the findings of the present study, Carvalho et al. (2016) reported that lower preovulatory circulating P4 concentration allowed the cows to ovulate more precociously compared with those with high plasma P4 concentration. These results can be evidenced by the fact that high circulating P4 concentrations reduce the LH pulsatility, triggering a negative feedback, which can diminish dominant follicle growth, causing it to present an inadequate development and a delay in reaching follicular maturity and, consequently, ovulation (Roberson et al. 1989). In this study, it was observed that smaller follicles demand more time for growth and development and thus reach the follicular maturity required for ovulation.

Macmillan et al. (1991) investigated the hormonal profile in ovariectomized Bos taurus taurus heifers treated with intravaginal devices containing $1.9 \mathrm{~g}$ P4 for 12 days and observed that the mean plasma $\mathrm{P} 4$ concentration in this period was $5.6 \mathrm{ng} / \mathrm{mL}$. According to Rahe et al. (1980), low LH pulsatility can be observed when plasma $\mathrm{P} 4$ concentrations are high, from 5 to $8 \mathrm{ng} / \mathrm{mL}$. Therefore, the high circulating P4 concentrations at the time of ovulation synchronization observed in the animals of the High-P4 group are close to the values found for pregnant cows (10.45ng/mL) (Rodrigues et al. 2018), and this hormonal scenario prevents follicular maturation and, consequently, ovulation from occurring. When cows are in a hormonal environment with high preovulatory circulating $\mathrm{P} 4$ concentrations, a negative feedback occurs in the secretion of GnRH by the hypothalamus, as well as decreased LH pulsatility, and this condition is determining for the development of smaller diameter follicles (Dias et al. 2009).

\section{CONCLUSIONS}

An endocrine environment with high preovulatory circulating progesterone (P4) concentration in a fixed-time artificial insemination (FTAI) synchronization protocol negatively influences follicular diameter and vascularization in crossbred cows.

Administration of equine chorionic gonadotrophin (eCG) at the time of removal of the intravaginal P4 device can be used as a strategy to favor better follicular response in cows with high plasma P4 levels at the time of ovulation synchronization due to the characteristic of this hormone in stimulating follicular growth and to its steroidogenic capacity, and it is an alternative to overcome the negative effects of high circulating P4 concentrations at the beginning of the synchronization protocol for FTAI.

Conflict of interest statement.- The authors have no competing interest.

\section{REFERENCES}

Acosta T.J. \& Miyamoto A. 2004. Vascular control of ovarian function: ovulation, corpus luteum formation and regression. Anim. Reprod. Sci. (82/83):127-140. <http://dx.doi.org/10.1016/j.anireprosci.2004.04.022> <PMid:15271448>

Acosta T.J., Hayashik G., Ohtani M. \& Miyamoto A. 2003. Local changes in blood flow within the preovulatory follicle wall and early corpus luteum in cows. Reproduction 125(5):759-767. <http://dx.doi.org/10.1530/ rep.0.1250759><PMid:12713439>

Baruselli P.S., Sales J.N.S., Sala R.V., Vieira L.M. \& Sá Filho M.F. 2012. History, evolution and perspectives of timed artificial insemination programs in Brazil. Anim. Reprod. 9(3):139-152.

Bó G.A., Baruselli P.S. \& Mapletoft R.J. 2013. Synchronization techniques to increase the utilization of artificial insemination in beef and dairy cattle. Anim. Reprod. 10:137-142.

Carvalho E.R., Martins T., Lamb G.C. \& Vasconcelos J. L. 2016. Ovulation time in suckled beef cows is anticipated by use of low doses of progesterone and temporary calf removal on fixed timed AI protocol. Theriogenology 86 (9):2238-2243. <http://dx.doi.org/10.1016/j.theriogenology.2016.07.015> <PMid: 27543363>

Carvalho J.B.P., Carvalho N.A.T., Reis E.L., Nichi M., Souza A.H. \& Baruselli P.S. 2008. Effect of early luteolysis in progesterone-based timed AI protocols in Bos indicus, Bos indicus $x$ Bos taurus, and Bos taurus heifers. Theriogenology 69(2):167-175. <http://dx.doi.org/10.1016/j.theriogenology.2007.08.035> <PMid:17980904>

De Rensis F. \& López-Gatius F. 2014. Equine chorionic gonadotropin to control reproduction of the dairy cows. Reprod. Domest. Anim. 49(2):177-182. <http://dx.doi.org/10.1111/rda.12268> <PMid:24456154>

Dias C.C., Wechsler F.S., Day M.L. \& Vasconcelos J.L.M. 2009. Progesterone concentrations, exogenous equine chorionic gonadotropin and timing 
of prostaglandin F2 $\alpha$ treatment affect fertility in pospuberal nelore heifers. Theriogenology 72(3):378-385. <http://dx.doi.org/10.1016/j. theriogenology.2009.03.006 ><PMid:19477500>

Fátima L.A., Binelli M., Baruselli P.S., Bonfim Neto A.P. \& Papa P.C. 2012. Angiogenic and steroidogenic responses of the corpus luteum after superovulatory and stimulatory treatments using ecg and fsh. Anim. Reprod. 9(3):273-280.

Ferreira R.M., Ayres H., Sales J.N.S., Souza A.H., Rodrigues C.A. \& Baruselli P.S. 2013. Effect of diferente doses of equine chorionic gonadotropin on folicular and luteal dynamics and p/ai of high-producting holteins cows. Anim. Reprod. Sci. 140(1/2):26-33. <http://dx.doi.org/10.1016/j. anireprosci.2013.04.014><PMid:23727121>

Honnens A., Niemann H., Herzog K., Paul V., Meyer H.H.D. \& Bollwein H. 2009. Relationships between ovarian blood flow and ovarian response to eCGtreatment of dairy cows. Anim. Reprod. Sci. 113(1/4):1-10. <http://dx.doi. org/10.1016/j.anireprosci.2008.05.077> <PMid:18619746>

Houghton P.L., Lemenager R.P., Moss G.E. \& Hendrix K.S. 1990. Prediction of postpartum beef cow body composition using weight to height ratio and visual body condition score. J. Anim. Sci. 68:1428-1437.

Macmillan K.L., Taufa V.K., Barnes D.R. \& Day A.M. 1991. Plasma progesterone concentrations in heifers and cows treated with a new intravaginal device. Anim. Reprod. Sci. 26(1/2):25-40. <http://dx.doi.org/10.1016/03784320(91)90063-6>

Murphy B.D. 2012. Equine chorionic gonadotropin: an enigmatic but essential tool. Anim. Reprod. 9(3):223-230.

Peres R.F.G., Claro Junior I., Sá Filho O.G., Nogueira G.P. \& Vasconcelos J.L.M. 2009. Strategies to improve fertility in Bos indicus postpubertal heifeirs and nonlactating cows submitted to fixed-time artificial insemination. Theriogenology 72(5):681-689. <http://dx.doi.org/10.1016/j. theriogenology.2009.04.026><PMid:19559472>

Pergorer M.F., Ereno R.L., Satrapa R.A., Pinheiro V.G., Trinca L.A. \& Barros C.M. 2011. Neither plasma progesterone concentrations nor exogenous ecg affects rates of ovulation or pregnancy in fixed-time artificial insemination (FTAI) protocols for puberal Nelore heifeirs. Theriogenology 75(1):17-23.<http:// dx.doi.org/10.1016/j.theriogenology.2010.07.005> <PMid:20833423>

Pfeifer L.F.M., Mapletoft R.J., Kastelic J.P., Small J.A., Adams G.P., Dionello N.J. \& Singh J. 2009. Effects of low versus physiologic plasma progesterone concentrations on ovarian follicular development and fertility in beef catle. Theriogenology 72(9):237-1250. <http://dx.doi.org/10.1016/j. theriogenology.2009.07.019>

Prata A.B., Pontes G.C.S., Monteiro Jr P.L., Drum J.N., Wiltbank M.C. \& Sartori R. 2017. Equine chorionic gonadotropin increase fertility of grazing dairy cows that receive fixed-time artificial insemination in the early but not later postpartum period. Theriogenology 98:36-40. <http://dx.doi. org/10.1016/j.theriogenology.2017.04.041><PMid:28601153>

Rahe C.H., Owens R.E., Fleeger J.L., Newton H.J. \& Harms P.G. 1980. Pattern of plasma luteinizing hormone in the cyclic cow: dependence upon the period of the cycle. Endocrinology 107(2):498-503. <http://dx.doi.org/10.1210/ endo-107-2-498><PMid:7190094>

Rigoglio N.N., Fátima L.A., Hanassaka J.Y., Pinto G.L., Machado A.S.D., Gimenes L.U., Baruselli P.S., Rennó F.P., Moura C.E.B., Watanabe I.L.-S. \& Papa P.C. 2013. Equine chorionic gonadotropin alters luteal cell morphologic features related to progesterone synthesis. Theriogenology 79(4):673-679. <http:// dx.doi.org/10.1016/j.theriogenology.2012.11.023><PMid:23273432>

Roberson M.S., Wolfe M.W., Stumpf T.T., Kittok R.J. \& Kinder J.E. 1989. Luteinizing hormone secretion and corpus luteum function in cows receiving two levels of progesterone. Biol. Reprod. 41(6):997-1003. <http://dx.doi. org/10.1095/biolreprod41.6.997><PMid:2624875>

Rodrigues A.S. 2016. Capacidade da dupla dose de PGF2 $\alpha$ associada ao eCG em ajustar o proestro de vacas mestiças leiteiras submetidas a um protocolo de IATF. Doctoral Dissertation, Universidade Federal da Bahia, Salvador, BA. 116p.

Rodrigues A.S., Silva M.A.A., Brandão T.O., Nascimento A. B., Bittencourt R. F., Chalhoub M., Bittencourt T. C. B. S. C. \& Ribeiro Filho A. L. 2018. Eficácia da associação dupla dose PGF2 alfa-eCG no porestro de vacas leiteiras mestiças submetidas a IATF. Pesq. Vet. Bras. 38(8):1518-1527. <http:// dx.doi.org/10.1590/1678-5150-pvb-5371>

Sá Filho M.F., Ayres H., Ferreira R.M., Marques M.O., Reis E.L., Silva R.C.P., Rodrigues C.A., Madureira E.H., Bó G.A. \& Baruselli P.S. 2010. Equine chorionic gonadotropin and gonadotropin-releasing hormone enhance fertility in a norgestomet-based, timed artificial insemination protocol in suckled nelore (Bos indicus) cows. Theriogenology 73(5):651-658. <http:// dx.doi.org/10.1016/j.theriogenology.2009.11.004><PMid:20080296>

Sales J.N.S., Carvalho J.B.P., Crepaldi G.A., Soares J.G., Girotto R.W., Maio J.R.G., Souza J.C. \& Baruselli P.S. 2015. Effect of circulating progesterone concentration during synchronization for fixed-time artificial insemination on ovulation and fertility in Bos indicus (Nelore) beef cows. Theriogenology 83(6):1093-1100.<http://dx.doi.org/10.1016/j.theriogenology.2014.12.009> $<$ PMid:25619807>

Savio J.D., Thatcher W.W., Morris G.R., Entwistle K., Drost M. \& Mattiacci M.R. 1993. Effects of induction of low plasma progesterone concentrations with a progesterone-releasing intravaginal device on follicular turnover and fertility in cattle. J. Reprod. Fertil. 98(1):77-84.<http://dx.doi.org/10.1530/ jrf.0.0980077><PMid:8345482>

Shephard R.W. 2013. Efficacy of inclusion of equine chrionic gonadotrophin into a treatment protocol for anoestrous dairy cows. New Zealand Vet. J. 61(6):330-336. <http://dx.doi.org/10.1080/00480169.2013.809633> $<$ PMid:23829605>

Siddiqui M.A.R., Almamun M. \& Ginther O.J. 2009. Blood flow in the wall of the preovulatory follicle and its relationship to pregnancy establishment in heifers. Anim. Reprod. Sci. 113(1/4):287-292.<http://dx.doi.org/10.1016/j. anireprosci.2008.07.008> <PMid:18768270>

Souza A.H., Viechnieski S., Lima F.A., Silva F.F., Araújo R., Bó G.A., Wiltbank M.C. \& Baruselli P.S. 2009. Effects of equine chorionic gonadotropin and type of ovulatory stimulus in a timed-AI protocolo in reproductive responses in dairy cows. Theriogenology 72(1):10-21. <http://dx.doi.org/10.1016/j. theriogenology.2008.12.025><PMid:19269685>

SPSS 2012. Introduction to Spss for windows version 19. Statistical Package for Social Science, Chicago. 85p.

Wiltbank M.C., Souza A.H., Carvalho P.D., Cunha P., Giordano J.O., Fricke P.M., Baez G.M. \& Diskin M.G. 2014. Physiological and practical effects of progesterone on reproduction in dairy cattle. Anim. Reprod. Sci. 8(Suppl.1):70-81. <PMid:24703103> 